\section{A COVID-19-járvány jótékony hatása \\ a háziorvosi gyakorlatra: a távkonzultáció és a telemedicina a racionalizálás lehetősége}

A SARS-CoV-2-pandémia gyökeresen megváltoztatta egész Európa és Magyarország családorvosi ellátását. Egyik napról a másikra szükségessé vált a korábban még jelentéktelennek tartott távkonzultáció alkalmazása. A betegkontaktus nélküli orvosi gyógyítás szükséges és hasznos volt, eredménye kézzelfogható. Március közepétől május elejéig elfogadottá vált, és a lakosság nemcsak megszokta, hanem annak gyakorlatához jól és eredményesen alkalmazkodott. Nagy segítség volt ebben az Egészségügyi Elektronikus Szolgáltatási Tér (EESZT).

A telemedicina, amely segíti és támogatja a távkonzultáció eredményességét, az egészségügyi szolgáltatások részévé vált, lehetőséget adott a hozzáférés (távolság/ akadályoztatás/kapacitáshiány) kritikus tényezőinek megoldásához. A jövőben megkönnyítheti az egészségügyi szolgálatok, a szakorvosok, a diagnosztika, a kezelések elérhetőségét. Eszközként alkalmazható a megelőzésben, a szükséges valós információkhoz jutásban, a kutatásban, valamint az egészségügyi szolgáltatók oktatásában. A telemedicináról az Orvosi Hetilapban a közelmúltban megjelent összefoglaló tanulmányhoz kívánunk hozzászólni az alapellátás szemszögéből, amely lehetőségeiben és hagyományaiban eltér az egészségügy más területeitól [1].

A betegek általában elégedettek az alapellátás keretében nyújtott távkonzultációkkal, beleértve a videókonzultációkat is [2] A betegeket hozzásegíti a szolgáltatók eléréséhez, csökkenthetik az egészségügyi ellátás akadályait (például szállítás, gyermekgondozás, kíséret igénye, várakozási idő). A videókonzultációt általában gazdasági szereplők biztosítják, a beteg által szokásosan igénybe vett ellátási intézménytól és az ellátási adatoktól, folyamattól elkülönülten. Az észak-kaliforniai Kaiser Permanente-ben a betegek többnyire az alapellátási és egyéb szolgáltatások igénybevételére is számítógépet vagy mobileszközöket használhatnak a videókonzultációkhoz. A kutatók 1200 felnőtt beteget vizsgáltak meg, akik videólátogatást terveztek: $82 \%$ uk megfelelőnek és elegendőnek tartotta a konzultációkat [3].

A betegek többsége $(87 \%)$ a videókonzultáció ütemezhetőségét kényelmes megoldásnak említette, $46 \%$ nem látta szükségesnek a személyes találkozást. A betegek több mint 90\%-a úgy gondolta, hogy videólátogatása megfelel az igényeinek, szolgáltatója ismeri a kórtörténetét, és a nyújtott ellátás minősége jó. Ennek ellenére a betegek csaknem fele (4l\%) inkább a személyes látogatásokat választaná. Mivel az amerikaiak egyre inkább online módon élnek - vásárlás, banki tevékenység, szocializáció -, az egészségügyi ellátás fizetőinek, szolgáltatóinak és sok munkáltatónak a számítógép vagy a mobileszköz által nyújtott elsődleges ellátás az egyik fó megoldása az egészségügyi költségek csökkentésére, miközben ezáltal az egészségügyi szolgáltatásokhoz való hozzáférés javul [2].

Hazánkban a veszélyhelyzet 6 . hetében megjelent a $157 / 2020$. (IV. 29.) Kormányrendelet a telemedicináról. A rendelet megvalósításában a jelenlegi helyzetben az EESZT és a Nemzeti Egészségügyi Alapkezelő (NEAK) rendszerek, valamint az informatikai lehetőségek alapot adnak a telemedicina-szolgáltatások számára. Ezt a folyamatot kényszerként támogatja a COVID-19járvány szükségszerű következménye.

A Magyar Általános Orvosok Tudományos Egyesülete (MÁOTE) négy háziorvosi körzetben 8 héten keresztül figyelte a betegellátás jellemzőit, a „zárt rendelők” hatását. A vészhelyzet kihirdetésének elsó három hetében nagy nyomás nehezedett a háziorvosokra. Ennek oka a kialakult helyzetnek a lakosságra gyakorolt váratlan és soha nem tapasztalt hatása, ami az orvosra és a praxisra is elmondható volt [4]. A kezdeti akár félezer heti telefonhívás és megszámlálhatatlan e-mail a közösségi médián keresztüli kommunikációval április közepére csillapodott, kiegyenlített lett, majd az „újraindítás” hírére megemelkedett. A 8 hét alatt (március 16.-május 8.) napi 46156 esemény ellátása történt; a május 4 . és május 8. közötti héten a telekonzultációt követően átlagosan napi 1,5 , személyes kontakttal járó vizsgálatra került sor

Egy körzetre vannak részletes és folyamatos adatok. A bejelentkezett lakosok száma 3078, egy háziorvos két nővérrel dolgozik: a két nővér a rendelőben, rendelési idő alatt, az orvos home office-ban május 4-ig. Kapcsolattartás mobiltelefonon, rendelői és otthoni e-mailen, közösségimédia-csoportban. Ez utóbbi segítségével napi információnyújtás minden felmerülő, személyes vagy csoportkérdésben. Az online csoport 974 felhasználót számlál, akikhez ha csak egy embert számolunk hozzá, akkor a praxis lakosainak többsége ilyen módon elérhető. A zárt rendelő időszakában nem maradt egyetlen ellátás sem befejezetlenül, lezáratlanul a SARS-CoV-2-fertőzöttek sürgôs beutalásától a mintavétel bonyolításán keresztül a tüdőembólia sürgős ellátásáig. Sor került járóbeteg-ellátással történő telefonkonzultációkra, valamint egy orvosi online közösségi csoportban képi és levelező konzultációkra is, sikeresen. 2461 adminisztrált esemény történt, ezek közül 1274 (51\%) esetben távkonzultációra került sor. A konzultációk naponta 10 és 12 óra között történtek, többségük a rendelési idő környékére sűrúsödött. A délutáni rendelések szinte egész nap folytak.

Korai, de ki lehet jelenteni, hogy a járványos időszak alatt, amely jelenleg kiszámíthatatlan idôtartamú lesz, egy új ellátás rend került bevezetésre. A korábbi tömeges rendelói megkeresések jelentős csökkentése sikeresen megtörtént. Ez kezdetben a COVID-19 terjedésének megakadályozása miatt elengedhetetlen volt, majd a későbbiekben a minőségi munka és az egészségügyi munkaerő megkímélése, a korábbi túlzó igénybevétel csökkentése útján elérhetővé vált. A telefonos megkereséseket a jövőben időkorlát (kijelölt időtartam) közé kell szorítani. A rendelési idő alatt a telefonkonzultációt korlátozni szükséges. A telefonos konzultáció egy szükség szerinti előjegyzés személyes vizsgálatra. A fokozatos visszatérés indulásakor a vizsgálatot igénylő betegek száma egy óra alatt legfeljebb 4 lehetett, heti 15 órában ez elegendőnek bizonyult. Ehhez egy mindenki számára konform elektronikus rendszer kialakítása elengedhetetlen.

A járványhelyzetben kialakult egy müködő alapellátási rendszer, amely érintheti a járóbeteg-ellátást is. Ez nem jelenti a jelenlegi struktúra lebontását, hanem múködésének racionális átalakítását és az eddigi 60-70 éves gyakorlat múködési struktúráját érintheti, leginkább a túlhaladott attitúdök, lakossági és egészségügyi szokások megváltozásával.

\section{Hivakozások}

[1] Győrffy Zs, Békási S, Szathmári-Mészáros N, et al. Possibilities of telemedicine regarding the COVID-19 pandemic in light of the international and Hungarian experiences and recommendations. [A telemedicina lehetőségei a COVID-19-pandémia kapcsán a nemzetközi és a magyarországi tapasztalatok és ajánlások tükrében.] Orv Hetil. 2020; 161: 983-992.

[2] Soloway B. reviewing Reed ME, et al. Tele medicine could lower barriers to primary care. Ann Intern Med. 2019 Apr 30. https: / /www.jwatch.org/na49035/ $2019 / 05 / 02 /$ telemedicine-could-lowerbarriers-primary-care

[3] Ladika S. Virtual primary care 'visits'? That future is already here. 2020 February 7. https://www.managedcaremag.com/archives $/ 2019 / 12 /$ virtual-primary-care-visits future-already-here

[4] Medicusonline: www.medicusuniversalis.hu

Balogh Sándor dr., Diós Erzsébet dr., Papp Renáta dr. (e-mail: balogh.sandor@pte.hu) 